\title{
肘部に発生した悪性軟部腫瘍の治療経験
}

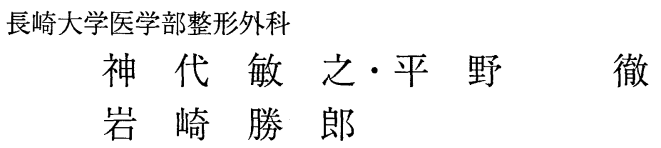

\section{Limb Salvage Procedures for Malignant Soft Tissue Tumors of the Elbow}

by

\section{Toshiyuki Kumashiro, Toru Hirano and Katsuro Iwasaki \\ Department of Orthopaedic Surgery Nagasaki University School of Medicine, Nagasaki}

\begin{abstract}
Malignant soft tissue tumors around the elbow occur less frequently than in either the shoulder or the wrist.

We reported six cases of malignant soft tissue tumors in the elbow that were treated by limb salvage procedures. Four Patients who had wide resection in which lateral side had no local recurrence, and two patients who had marginal resection in which medial or antecubital side had local recurrence. Except one case, the functions of the preserved limb were comparatively good, in spite of lateral side wide resection of the extensor muscles.

So, it seems that usual wide resection in the elbow is enough to secure the useful function of the affected limbs.
\end{abstract}

\section{はじめに}

肘関節周辺に発生した悪性軟部腫瘍の患肢温存治療 において，ここには重要な神経や血管が多数分布して おり，しかも safty marginを得るための軟部組織 がそしいため，局所再発を防ぎ，かつ良好な患肢機能 を温存することは困難な場合が多( 1),4),5), 6),7). 今回, 我々は肘部に発生した悪性軟部腫瘍の治療結果につい て温存患肢機能の面から検討を加えた。

\section{対象および方法}

当科で患肢温存治療を試みた，肘部発生の悪性軟部 腫瘍 6 例を対象とした（表 1 ）。その内訳は悪性線維 性組織球腫 (MFH) 3 例, 滑膜肉腫 2 例，横紋筋肉 腫 1 例である。手術時年齢は 11 カ月から 75 歳で，観 察期間は 4 力月から 4 年 1 カ月である。腫瘍の発生 部位は时部外側 4 例，内側 1 例，屈側 1 例であった. Enneking ${ }^{2)}$ の surgical staging systemによると
1 例が II - A で他の 5 例は II - B であった。補助療法 は, 術前, 術後に化学療法のみ行ったもの 2 例, 化学 療法と放射線療法の併用療法を行ったもの 2 例，放射 線療法のみ行ったもの 1 例である. 術後の患肢機能は Enneking の基準によって評価した。その際 emotional acceptanceは除外した ${ }^{3)}$.

結果

初回手術時の切除縁の評価は, 外側発生の 4 例で wide margin が得られていたが, 内側と屈側の 2 例 では marginal margin であった（表 1 ). 局所再発 は marginal margin の内側と屈側の 2 例で認めら れ，いずれも上腕からの切断を行った. Wide margin で腫瘍を摘出した外側発生の 4 例では，患肢は温存さ れている。 それらの手術内容は，症例 $1 ， 2 ， 3$ では 上腕骨外顆と伸筋群を切除しており, そのうち症例 2 では橈骨神経も切除した。症例 4 では伸筋群のみを切 除した. Enneking の総合評価では, 症例 1，2，3， 
表 1 症例一覧

\begin{tabular}{|c|c|c|c|c|c|c|c|c|c|c|c|c|}
\hline 症例 & 年齢 & 性 & 部位 & 診断 & Stage & 補助療法 & 切除縁 & 局所再生 & 遠隔転移 & 機能評価 & & 6後 \\
\hline 1 & 75 & 男 & 外側 & $\begin{array}{l}\text { 墨性線維性 } \\
\text { 組織球腫 }\end{array}$ & II - B & $\mathrm{C}$ & wide & $(-)$ & $(-)$ & G & $\mathrm{DF}$ & 19 カ月 \\
\hline 2 & 60 & 女 & " & " & " & $\mathrm{R}$ & wide & $(-)$ & $(+)$ & F & NED & 17 カ月 \\
\hline 3 & 61 & 女 & " & " & " & $(-)$ & wide & $(-)$ & $(-)$ & G & $\mathrm{DF}$ & 4 カ月 \\
\hline 4 & 11 力月 & 女 & " & 横紋筋肉腫 & II - A & C & wide & $(-)$ & $(-)$ & $\mathrm{E}$ & $\mathrm{DF}$ & 34 力月 \\
\hline 5 & 40 & 男 & 内側 & 滑膜肉腫 & II - B & $C+R$ & marginal & $(+)$ & $(+)$ & $\mathrm{P}$ & DOD & 24 力月 \\
\hline 6 & 19 & 女 & 屈側 & " & " & $C+R$ & marginal & $(+)$ & $(+)$ & $\mathrm{P}$ & DOD & 49 力月 \\
\hline
\end{tabular}

C ; Chemotherapy, R ; Radiation, E ; Excellent, G ; Good, F ; Fair, P ; Poor, $\mathrm{DF}$; disease free, NED ; no evidence of disease, DOD ; dead of disease

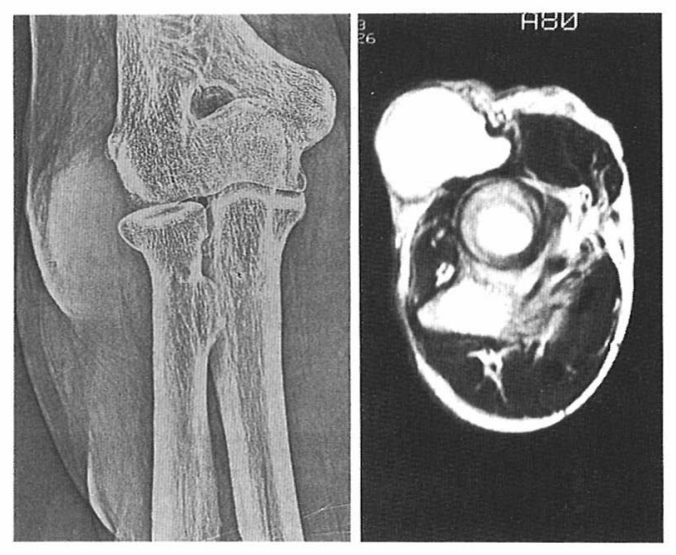

(A)
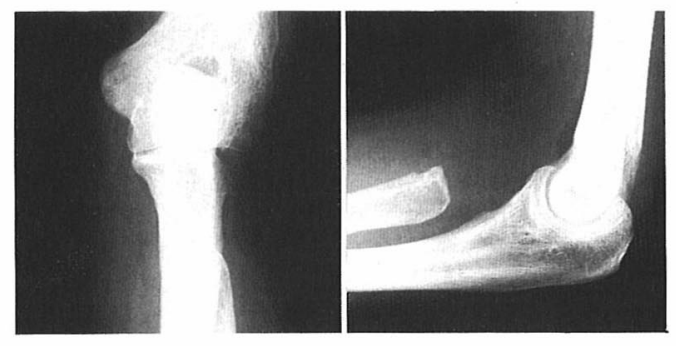

(B)

図 1 症例 1, 75 歳男性. 时部外側に発生した悪性 線維性組織球腫. (A) 腫瘍は主に皮下組織内 にあり，一部筋肉内に浸潤している。（B）上 腕骨外顆と橈骨近位 $3 \mathrm{~cm}$ を切除した.

4 それぞれ, good, fair, good, excellentであっ た. 項目別では, stability, strength, functional activity が他の項目より悪かった.

代表的症例の詳細を以下に示す.

症例 1 : 75 歳男性, 肘部外側発生の MFH. 腫瘍

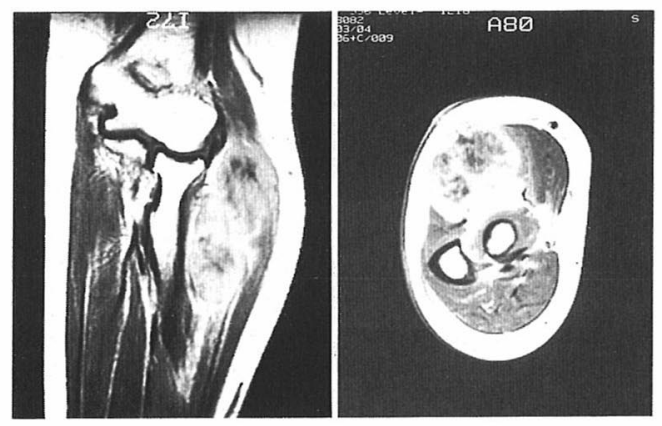

(A)
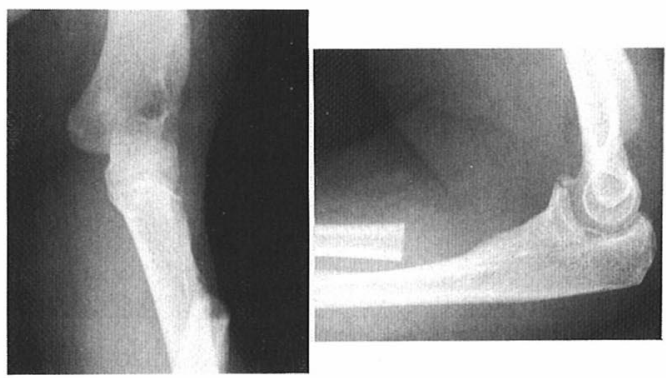

(B)

図2 症例 2, 60 歳女性. 时部外側に発生した悪性 線維性組織球腫. (A) 腫瘍は腕橈骨筋内に認 められる. 術前に $30 \mathrm{~Gy}$ の放射線療法を行っ た.（B）上腕骨外顆と橈骨近位 $5 \mathrm{~cm}$ を切除し, 伸筋群の再建を行った.

は主に皮下組織内にあり一部筋肉内に浸潤していた。 腕橈骨筋の内側 $1 / 3$ を残し, 他の伸筋群, 上腕骨外 顆, 橈骨近位 $3 \mathrm{~cm}$ を一塊として切除した. 摘出標本 で切除縁は wide marginであった。局所再発はな く, lateral instability を軽度認め, 筋力低下のた め回内位で物をもつのに不自由である（図 1). 


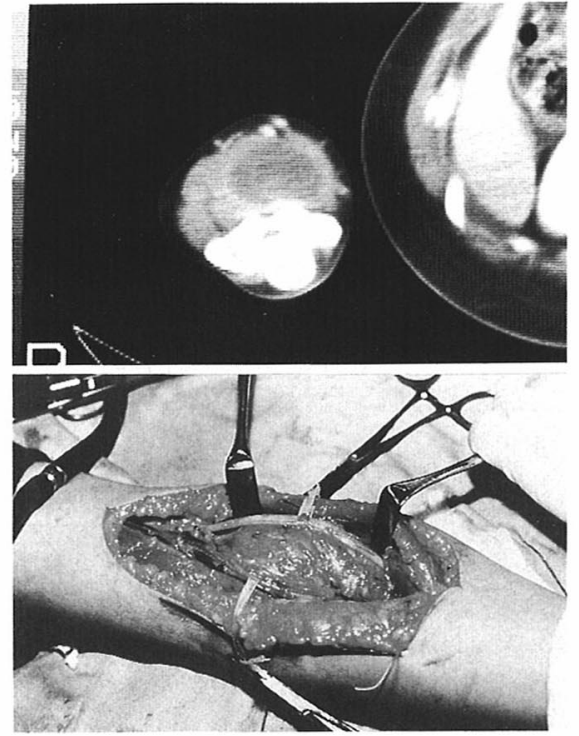

図 3 症例 6,19歳女性. 时部屈側に発生した滑膜 肉腫. 腫瘍は上腕筋, 円回内筋部に見られる. 正中神経が腫瘍の直上に見られた。

症例 2：60 歳女性, 外側発生の MFH. MRI 像で, 腫瘍は主に腕橈骨筋内に認められるが，回外筋や橈骨 骨皮質にも一部浸潤していると思われたため, 術前に $30 \mathrm{~Gy}$ の放射線療法を行った。伸筋群の全てと回外筋, 上腕骨外顆と橈骨近位 $5 \mathrm{~cm}$ を一塊に切除したが，そ の際, 橈骨神経の深枝も切除した。 そして, Riordan 法により拇指および手指の伸展機能の再建を行った。 摘出標本の切除縁は, wide marginであった. 局所 再発は認めていないが，胸部に転移巣を認めたためこ れに対して外科的に切除した. 術後の機能評価は患肢 では筋力の低下と不安定性のため対側肢の手助けを要 するが，指の功緻性はほほ良好である（図 2).

症例 6：19 歳女性, 屈側発生の滑膜肉腫. 腫痬は $\mathrm{CT}$ 上，上腕筋，円回内筋部に見られた. Wide margin による患肢温存手術は困難と考え術前に化学療法 と放射線㙩法を行ない, marginal marginの腫瘍 摘出術を行った。術後にも化学療法と放射線療法を行っ たが， 1 年後に局所再発を来たし，上腕中央部で切断 した（図 3 ).

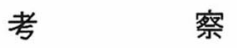

解剖学的に肘部には重要な神経・血管が広く分布し
ているため，悪性軟部腫瘍の治療に際して広範切除を 行うとこれらの切除が必要となり, 温存患肢機能の障 害が高度となることが予想されている4),6),7)。しかし 四肢に発生する悪性軟部腫瘍で，肘部に発生するもの は非常に少なく広範切除によって生じる機能障害につ いて言及した報告は少ない1)。 そこで今回，我々が治 療した症例を検討した結果, 肘部内側と屈側発生例の 治療結果から切除縁を marginal ですると局所再発 し, 結局切断となっていることから, wide margin での思い切った切除が必要と思われる。これによって 機能障害が重篤となっても，切断よりも機能はましで あろう。これに対して时部外側発生例では，橈骨神経 の切除を余儀なくされた 1 例を除くと, 上腕骨外顆や 橈骨近位部を切除し，伸筋群を広範囲に切除したのに 拘わらず, Enneking の機能評価では good 以上の良 好な患肢機能が得られた，橈骨神経を切除した 1 例で もその肘関節機能は fairであるものの, 手指機能の 再建により有用な上肢として機能しており，悪性軟部 腫瘍の肘部外側発生例では，他の部位の悪性軟部腫瘍 と同様広範切除縁でも，比較的満足すべき患肢機能が 得られることがわかった.

\section{ま と め}

(1)时部に発生した悪性軟部腫瘍のうち患肢温存治療 を行った 6 例の治療結果を臨床的に検討した.

(2)外側発生の 4 例では wide marginの確保がで き局所再発はみられなかったが，内側と屈側の 2 例で は marginal margin となり局所再発したため上腕 切断を行った.

(3)外側発生の 4 例のうち 3 例は上腕骨外顆や橈骨近 位部を切除し，そのうちの 1 例では橈骨神経の切除も 余儀なくされた，橈骨近位部と橈骨神経を切除した症 例を除いて，肘部で伸筋群を広範に切除したにも拘わ らず，温存患肢機能は良好であった。

(4)肘部の悪性軟部腫瘍の患肢温存治療で外側発生例 では, 他の部位発生の悪性軟部腫瘍と同様の局所再発 を来さないような切除縁でも，比較的満足すべき患肢 機能が得られることがわかった。

\section{参 考 文 献}

1) Enneking, W.F.: Musculoskeletal tumor surgery, pp. 421-436. Edited by W.F. Enneking. New York, 
Churchill Livingstone, 1983.

2) Enneking, W.F.: A system of staging musculoskeletal neoplasms. Clin. Orthop., $204:$ 9-24, 1986.

3) Enneking, W.F.: A modified system for the functional evaluation of the surgical management of musculoskeletal tumors. International symposium on limb salvage in musculoskeletal oncology, Kyoto, 1987.

4）川口智義・他 : 上肢悪性軟部腫瘍の患肢温存手術と機 能評価・整・災外, $33: 1593-1600,1990$.

5) Simon, M.A. et al.: The management of soft-tissue sarcomas of the extremities. J.Bone and Joint Surg., 58-A : 317-327, 1976.

6) Shiu, M.H. et al.: Limb preservation and tumor control in the treatment of popliteal and antecubital soft tissue sarcomas. Cancer, $57: 1632-1639,1986$.

7）姥山勇二・他：上肢発生の悪性軟部腫瘍について．臨 整外，25:943-950，1990。
質 問

琉球大学 井上治

前腕伸側の広範切除後，実際にどのように腱移行術 をされたか.

解 答

長崎大学 神代 敏之

再建法について

Pronator teres と Flex. carpi ulnaris, Palmaris longus を伸筋群に利用している.

追 加 九州大学 岩本 幸英

Enneking の機能評価は 1989 年頃群点数評価に生 じているので, 最新の評価基準を用いるべきたど思う.

解 答

長崎大学 神代 敏之

Enneking の評価法は 1987 年に発表したものを用 いた. 